\title{
ANALYSIS OF REVERSE SUPPLY CHAIN PERFORMANCE IN BEEF INDUSTRY WITH THE SUPPLY CHAIN OPERATION REFERENCE METHOD
}

\section{ANALISIS KINERJA REVERVE SUPPLY CHAIN PADA INDUSTRI DAGING SAPI DENGAN METODE SUPPLY CHAIN OPERATION REFERENCE}

\author{
Paduloh Paduloh*, Dyani Kalyana Mitta, Sumanto, Rifda Ilahy Rosihan \\ Industrial Engineering, Bhayangkara Jakarta Raya University \\ Jl. Perjuangan No. 81, RT 001/RW 002, Marga Mulya, Kec. Bekasi Utara, \\ Kota Bekasi, Jawa Barat 17143 \\ Email:*paduloh@dsn.ubharajaya.ac.id
}

Makalah: Diterima 09 Novmber 2020; Diperbaiki 20 Desember 2020; Disetujui 26 Desember 2020

\begin{abstract}
ABSTRAK
Pengelolaan produk retur dari pelanggan sangat mendesak untuk mengurangi kerugian perusahaan yang lebih besar akibat produk yang dikembalikan dari pelanggan. Manajemen produk yang dikembalikan seringkali bukan prioritas bagi perusahaan. Oleh karena itu, penelitian ini mencoba mengukur kinerja pelaku rantai pasok di sepanjang rantai pasok balikan daging sapi. Analisis menggunakan SCOR dan pembobotan nilai menggunakan AHP, kemudian menghitung perbandingan indikator kinerja utama dengan Objective Matrix. Hasil analisis menggunakan Objective Matrix dan Sistem Traffic Light dengan 16 indikator untuk proses pengiriman dan penarikan menunjukkan kesembilan indikator tersebut masih jauh dari target. Akibatnya ketiga indikator tersebut tidak mencapai tujuan, dan keempat indikator tersebut mencapai satu sasaran. Indikator ini menunjukkan urgensi peningkatan kinerja perusahaan, yaitu indikator resale produk yang telah diperbaiki, lead time pengiriman dan penarikan produk, pemeriksaan kualitas, dan peningkatan fasilitas produk. Hasilnya menunjukkan potensi peningkatan berkelanjutan untuk meningkatkan kinerja rantai pasokan balik daging sapi, mengoptimalkan biaya yang digunakan, dan mengurangi risiko di sepanjang rantai pasokan balik. Hasil analisis juga menunjukkan nilai tertinggi dan persentase terendah, yaitu 1.210 dan 72\%, yaitu banyaknya produk yang dapat dijual kembali terhadap produk yang dikembalikan. Penelitian ini memiliki kebaruan dalam mengukur kinerja balik rantai pasok yang belum pernah dilakukan sebelumnya.
\end{abstract}

Kata kunci: daging sapi, OMAX, KPI, reverse supply chain, COR, traffic light system

\begin{abstract}
Management of returned products from customers is very urgent to reduce the company's bigger losses due to products returned from customers. Management of returned products is often not a priority for companies. For this reason, this study tried to measure supply chain actors' performance along the beef reverse supply chain. Analysis used SCOR and weighting values used AHP, then calculating the comparison of the main performance indicators with the Objective Matrix. The analysis results using the Objective Matrix and Traffic Light System with 16 indicators for the delivery and withdrawal process showed that the nine indicators were still far from the target. As a result, the three indicators did not achieve the goal, and the four indicators achieved one target. This indicator showed the urgency of improving company performance, namely, product resale indicators that have been repaired, lead time for product delivery and recall, quality inspection, and product facility improvement. The results showed the potential for continuous improvement to improve the beef reverse supply chain's performance, optimize the costs used, and reduce risks along the reverse supply chain. The analysis results also show the highest values and the lowest percentages, namely 1,210 and 72\%, which were the number of products that can be resold against returned products. This research has a novelty in measuring supply chain reverse performance that has never been done before.
\end{abstract}

Keywords: beef, OMAX, KPI, reverse supply chain, SCOR, traffic light system

\section{INTRODUCTION}

Beef is an agro-industrial product that is easily damaged, so to extend the shelf life of the product requires special handling such as shipping using cold chains. Fluctuating demand for beef has an impact on many factors, such as excess and insufficient supply. Customers experience the same condition. In previous research (Paduloh et al., 2020), it was found that the reason for returning products from customers to distributors or suppliers is because of service contracts and product quality that has decreased. It is not according to specifications, expired, no longer sold, delivery errors, and delivery times that do not match the request. Returning products from customers also have an economic and environmental 
impact where the returned product requires handling creating costs and product damage risks.

Previous research on handling the return of beef products has been carried out. Optimize the quality of beef by preventing product returns by improving forecasting and recording systems, then optimizing the cost of beef quality inspection and optimizing the cost of repairing meat cows retrieved from customers. Lu et al. (2019) conducted a study on the effect of storing chill beef on shelf life for beef cases in China. They analyzed the preservation of beef. Research on reverse supply chains has also been done a lot (Paduloh et al., 2020). His literature study found that manufactured products and retail and supermarket products are the most discussed products besides products in general. Research on reverse supply chain also discusses a lot about optimization to maximize reverse supply chain costs. Research on the measurement of reverse supply chain performance has never been done before, and discussion of supply chain performance measurement is mostly done for the forward supply chain.

It is necessary to measure the supply chain's performance for returned products, considering a large number of products returned. This measurement of supply chain performance will help the company improve its performance and improve performance that is still lacking. Many types of research on supply chain performance have been conducted (Delipinar et al., 2016); in their literature review found for the strategy to usages of SCOR model with success is making a strategic alignment between business and information technologies, the scope of the SCOR model, ERP, and performance measures. Akkawuttiwanich et al. (2018) developed the fuzzy QFD approach to manage SCOR KPIs in the industrial case study. Sundarakani et al. (2018) analyzed competitive advantage for catering supply chain in the flight industry. Djatna et al. (2020) studied the measurement performance with SCOR integration of JavaScript-based front-end and its data is ready for mobile and desktop usage. In this study, we use SCOR to determine the reverse supply chain performance of beef and highlight the performance of the delivery, return, and repair process of the returned product so that it does not get damaged.
Based on case studies, we found that many products were returned from customers. In this study, PT XYZ is a company engaged in the distribution of beef. All customer areas, including customers around major cities. As shown in Table 1, the number of beef product returns creates many product recall problems and handling of returned products.

This study aimed to measure the performance of the beef reverse supply chain to determine its performance and make improvements to make it more effective and efficient. Besides that, to analyze the performance of the beef reverse supply chain using AHP, objective matrix, and light traffic systems to get optimal results on the performance of the beef reverse supply chain.

\section{MATERIALS AND METHODS}

The research was conducted at PT XYZ beef distributor. The focus of this research measures the reverse supply chain performance of the product delivery and return process. Data collection was carried out to find out the information needed to conduct research.

Based on Figure 1 above, there are two types of data needed, namely primary and secondary data. Primary data is data obtained from questionnaires and direct observations on the company. Meanwhile, secondary data is existing data or general and historical company data. In this study, data collection was carried out using an instrument, namely a questionnaire to explore or reveal related reverse supply chain performance.

The details of the steps to obtain comparison and validation data are as follows (Paduloh et al. 2020); Hamidah et al., 2013):

a. Comparing of each scale value with the number of its columns, the number of columns can be calculated by the formula:

$$
S i=\sum_{i=0}^{n} k i j=k j 0+k j 1+\cdots+k j n .
$$

b. Normalize columns and specify priority vector,

c. Pairwise comparison matrix multiplied by priority vector.

d. The value of the total weight vector is divided by the priority vector

Table 1. Conditions for returning beef in 2019

\begin{tabular}{lccccccc}
\hline \multicolumn{1}{c}{ Kategori } & $\begin{array}{c}\text { September } \\
(\mathbf{K g})\end{array}$ & $\begin{array}{c}\text { October } \\
(\mathbf{K g})\end{array}$ & $\begin{array}{c}\text { November } \\
(\mathbf{K g})\end{array}$ & $\begin{array}{c}\text { December } \\
(\mathbf{K g})\end{array}$ & $\begin{array}{c}\text { January } \\
(\mathbf{K g})\end{array}$ & $\begin{array}{c}\text { February } \\
(\mathbf{K g})\end{array}$ & $\begin{array}{c}\text { Total } \\
(\mathbf{K g})\end{array}$ \\
\hline Specification & 471.18 & 52.63 & 189.86 & 78.08 & 22.79 & $1,156.68$ & $1,971.22$ \\
Delivery & 129.36 & 438.24 & $2,038.86$ & $3,172.67$ & 7.26 & - & $5,786.39$ \\
Process & & & & & & & \\
Product & 341.80 & 60.79 & 488.65 & 76.16 & 452.22 & 20.76 & $1,440.38$ \\
Quality & $1,792.00$ & $1,223.00$ & $1,731.73$ & $2,129.73$ & 321.70 & 825.21 & $8,023.37$ \\
Person & 197.50 & 207.40 & 394.97 & $3,512.11$ & - & - & $4,311.98$ \\
Packaging & 34.00 & 71.00 & 83.00 & - & - & 17.80 & 205.80 \\
Uncategorized & $\mathbf{2 , 9 6 5 . 8 4}$ & $\mathbf{2 , 0 5 3 . 0 6}$ & $\mathbf{4 , 9 2 7 . 0 7}$ & $\mathbf{8 , 9 6 8 . 7 5}$ & $\mathbf{8 0 3 . 9 7}$ & $\mathbf{2 , 0 2 0 . 4 5}$ & $\mathbf{2 1 , 7 3 9 . 1 4}$ \\
\hline Total & & & & & & & \\
\hline
\end{tabular}


Source: PT XYZ Data Processing (2019)

e. Determine the max $\lambda$ value using

$$
\lambda \text { maks }=\frac{\sum_{i=0}^{n} a_{i}}{n}
$$

f. Calculating of consistency index (CI)

$$
C I=\lambda \operatorname{maks}-n n-1
$$$$
C I=\frac{\lambda \text { maks }-n}{n-1}
$$

g. Calculating consistency ratio (CR),

$$
C R=\frac{C I}{R I}
$$

Remarks :

$$
\begin{array}{lll}
\sum_{i=0}^{n} a_{i} & =\text { Number of matrix } \\
\lambda \text { maks } & =\begin{array}{l}
\text { The largest eigenvalues of the } \\
\text { ordered metric } n
\end{array} \\
\mathrm{n} & =\begin{array}{l}
\text { number of criteria } \\
\mathrm{CI}
\end{array} & \text { Consistency Index } \\
\mathrm{CR} & = & \text { Consistency Ratio } \\
\mathrm{RI} & =\begin{array}{l}
\text { Random Index Scoring System } \\
\text { calculation using OMAX }
\end{array}
\end{array}
$$

h. Identifying KPIs with a traffic light system (TLS).

\section{RESULT AND DISCUSSION}

The supply chain that occurs in beef products, namely lives cows originating from breeders, then distributed to cow collectors or even into slaughterhouses, beef that has been slaughtered, then goes into cold storage, fresh beef can also be sold directly to markets, shops, and other areas. Before

\begin{tabular}{|c|c|c|c|c|c|c|c|c|c|}
\hline NO & KPI & Unit & Sept & Oct & Nov & Dec & Jan & Febr & Mean \\
\hline 1 & $\begin{array}{l}\text { The number of the product } \\
\text { that success to deliver }\end{array}$ & $\mathrm{Kg}$ & 78,300 & 79,100 & 79,600 & 79,900 & 78,300 & 78,800 & 79,000 \\
\hline 2 & Accuracy delivery & $\%$ & 86 & 87 & 89 & 85 & 90 & 87 & 87 \\
\hline 3 & On-time delivery & hour & 21 & 19 & 16 & 19 & 17 & 18 & 18 \\
\hline 4 & $\begin{array}{l}\text { The number of the product } \\
\text { that can be carried out }\end{array}$ & $\mathrm{Kg}$ & 550 & 670 & 750 & 800 & 430 & 400 & 600 \\
\hline 5 & $\begin{array}{l}\text { The speed of delivery for } \\
\text { sudden request }\end{array}$ & $\%$ & 80 & 85 & 75 & 85 & 82 & 70 & 80 \\
\hline 6 & The Good Product Return & Unit & 93 & 95 & 94 & 212 & 45 & 61 & 100 \\
\hline 7 & $\begin{array}{l}\text { The number of product that } \\
\text { can be renewed }\end{array}$ & Unit & 78 & 80 & 85 & 100 & 50 & 47 & 73 \\
\hline 8 & $\begin{array}{l}\text { The number of less desirable } \\
\text { product }\end{array}$ & Unit & 43 & 50 & 57 & 45 & 50 & 55 & 50 \\
\hline 9 & $\begin{array}{l}\text { The number of low-quality } \\
\text { product }\end{array}$ & Unit & 40 & 35 & 40 & 60 & 35 & 30 & 40 \\
\hline 10 & $\begin{array}{l}\text { Product return against a } \\
\text { maximum capacity }\end{array}$ & $\mathrm{Kg}$ & 400 & 532 & 615 & 310 & 475 & 519 & 475 \\
\hline 11 & $\begin{array}{l}\text { Processing time to pick the } \\
\text { product }\end{array}$ & Hour & 20 & 24 & 20 & 22 & 23 & 21 & 22 \\
\hline 12 & $\begin{array}{l}\text { The number of product } \\
\text { return }\end{array}$ & Hour & 19 & 19 & 17 & 23 & 20 & 20 & 20 \\
\hline 13 & $\begin{array}{l}\text { The number of product } \\
\text { resold }\end{array}$ & Unit & 75 & 70 & 49 & 30 & 73 & 60 & 60 \\
\hline 14 & $\begin{array}{l}\text { The number of product } \\
\text { reused }\end{array}$ & Unit & 63 & 45 & 41 & 30 & 45 & 50 & 46 \\
\hline 15 & $\begin{array}{l}\text { The number of allocated } \\
\text { product }\end{array}$ & Unit & 28 & 30 & 35 & 23 & 30 & 33 & 30 \\
\hline 16 & $\begin{array}{l}\text { The number of disposing of } \\
\text { the product }\end{array}$ & Unit & 28 & 22 & 21 & 26 & 20 & 26 & 24 \\
\hline
\end{tabular}
data processing, the necessary data was collected in the study. The data collected in this research is in data on product shipments and product returns in the last six months. Moreover, from the information on the return data of existing beef products, the shipping and product return data used 16 indicators. The measurement was implemented along the supply chain from product shipped until return to the company. The data is described in Table 2.

Table 2. Data on beef delivery and returns

Source: PT XYZ (2019) 


\section{Determining Measured Parameters}

KPI identification was carried out for the KPI preparation process based on the objective category of each KPI, which aimed to see the relevance of each KPI with performance measurement. The Questionnaire data distributed to respondents and data from interviews to informants. Before distributing questionnaires to the sources, first, determined the sources. The sampling technique used in determining the sources was nonprobability sampling with the Judgment Sampling method (based on considerations), where the sources obtained were employees of the leadership of PT XYZ. The sampling technique was chosen because the leadership employees were considered competent experts in the factory. This interview's results were discussed again with the plant manager and processing assistants to obtain several items of performance parameters that were following the actual conditions at PT XYZ. Table 3 showed the Key Performance Indicator (KPI) indicators or parameters for which the performance was measured. The group measures sixteen performance parameters to deliver or product returns and product returns. KPIs were measured to have two types: large, the better, and smaller, the better.

\section{SCOR Model}

The performance measurement was mapped with the SCOR model. It aimed to get the attributes for each KPI. The performance mapping to be measured can be seen in Figure 2.

\section{Weighting with AHP}

Creating and weighing KPI hierarchies 1, 2, and 3 used the AHP (Analytical Hierarchy Process) method, especially using pairwise comparison matrix calculations (Sirous et al., 2016). The first step in weighting KPI metrics was to design the AHP hierarchical structure starting with a goal or objective, followed by a classification from levels 1,2, and 3, namely five core processes, three performance attributes, and ending with KPI metrics.

Table 3. Identification of KPI parameters

\begin{tabular}{|c|c|c|c|c|}
\hline No. & $\begin{array}{l}\text { KPI } \\
\text { No. }\end{array}$ & KPI & Information & $\begin{array}{c}\text { Type } \\
\text { KPI }\end{array}$ \\
\hline 1 & D1.1 & $\begin{array}{l}\text { Perfect order } \\
\text { fulfillment }\end{array}$ & $\begin{array}{l}\text { The number of products that successfully delivered } \\
\text { against consumer demand }\end{array}$ & Large the better \\
\hline 2 & D1.2 & Order accuracy & The accuracy of the delivered goods to costumer & Large the better \\
\hline 3 & $\mathrm{D} 2.1$ & $\begin{array}{l}\text { Customer commit } \\
\text { date }\end{array}$ & On-time delivery against total delivery time & $\begin{array}{l}\text { Smaller the } \\
\text { better }\end{array}$ \\
\hline 4 & $\mathrm{D} 2.2$ & $\begin{array}{l}\text { \% Utility of } \\
\text { truckload }\end{array}$ & $\begin{array}{l}\text { The number of products a vehicle can carry against the } \\
\text { vehicle capacity }\end{array}$ & Large the better \\
\hline 5 & D3 & $\begin{array}{l}\text { delivery for sudden } \\
\text { request }\end{array}$ & Delivery rate to satisfy demand customer & Large the better \\
\hline 6 & $\mathrm{R} 1.1$ & Good product return & $\begin{array}{l}\text { The number of product return with good quality against } \\
\text { delivery product }\end{array}$ & $\begin{array}{l}\text { Smaller the } \\
\text { better }\end{array}$ \\
\hline 7 & $\mathrm{R} 1.2$ & $\begin{array}{l}\text { Refurbish product } \\
\text { return }\end{array}$ & $\begin{array}{l}\text { The number of the product that can be updated against } \\
\text { delivery product }\end{array}$ & $\begin{array}{l}\text { Smaller the } \\
\text { better }\end{array}$ \\
\hline 8 & $\mathrm{R} 1.3$ & $\begin{array}{l}\text { Leased product } \\
\text { return }\end{array}$ & $\begin{array}{l}\text { The number of products that are less desirable for the } \\
\text { products that were successfully delivered }\end{array}$ & $\begin{array}{l}\text { Smaller the } \\
\text { better }\end{array}$ \\
\hline 9 & $\mathrm{R} 1.4$ & EOL product return & $\begin{array}{l}\text { The number of low-quality products against delivery } \\
\text { product }\end{array}$ & $\begin{array}{l}\text { Smaller the } \\
\text { better }\end{array}$ \\
\hline 10 & $\mathrm{R} 2.1$ & $\begin{array}{l}\text { \% Utility of } \\
\text { truckload return }\end{array}$ & $\begin{array}{l}\text { Comparison of taking return goods with maximum } \\
\text { retrieval capacity }\end{array}$ & $\begin{array}{l}\text { Large the } \\
\text { better }\end{array}$ \\
\hline 11 & $\mathrm{R} 2.2$ & $\begin{array}{l}\text { Deliver return cycle } \\
\text { time }\end{array}$ & The amount of time to process goods & $\begin{array}{l}\text { Smaller the } \\
\text { better }\end{array}$ \\
\hline 12 & $\mathrm{R} 2.3$ & Return cycle time & The amount of time to complete the returned product. & $\begin{array}{l}\text { Smaller the } \\
\text { better }\end{array}$ \\
\hline 13 & $\mathrm{R} 3.1$ & Resell product & $\begin{array}{l}\text { The number of the product that can be resold with a good } \\
\text { quality product }\end{array}$ & $\begin{array}{l}\text { Smaller the } \\
\text { better }\end{array}$ \\
\hline 14 & $\mathrm{R} 3.2$ & $\begin{array}{l}\text { Repair product for } \\
\text { send back }\end{array}$ & $\begin{array}{l}\text { The number of products that can be reused against } \\
\text { renewable products }\end{array}$ & $\begin{array}{l}\text { Smaller the } \\
\text { better }\end{array}$ \\
\hline 15 & $\mathrm{R} 3.3$ & Release product & $\begin{array}{l}\text { the number of products that can be allocated to less } \\
\text { desirable products }\end{array}$ & $\begin{array}{l}\text { Smaller the } \\
\text { better }\end{array}$ \\
\hline 16 & R3.4 & Disposal product & $\begin{array}{l}\text { The number of the product that can be disposed of against } \\
\text { low-quality product }\end{array}$ & $\begin{array}{c}\text { Smaller the } \\
\text { better }\end{array}$ \\
\hline
\end{tabular}




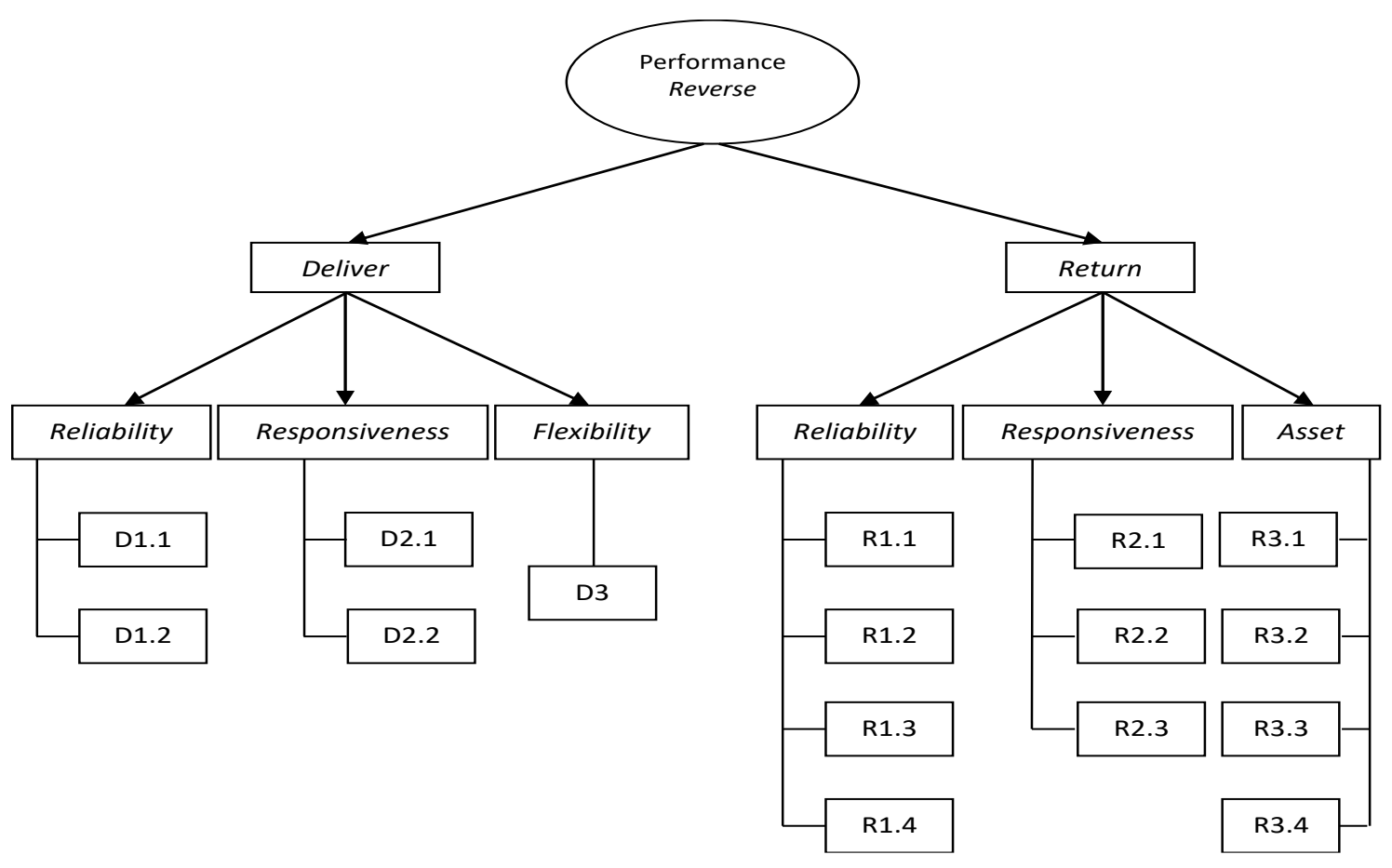

Figure 2. Mapping of reverse performance with the SCOR model

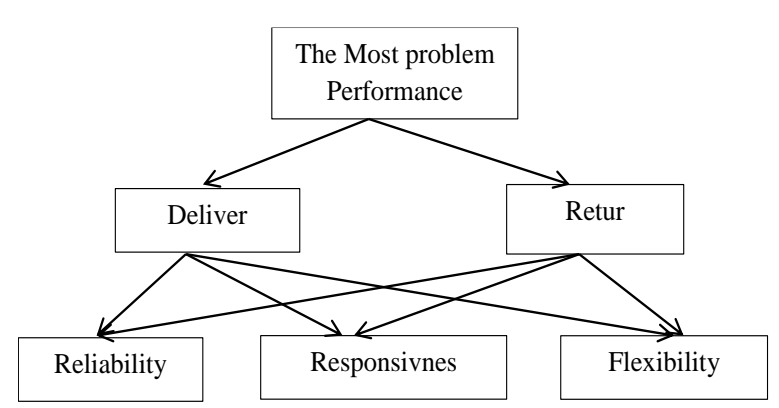

Figure 3. AHP framework

To create and weighting AHP, it used questionnaire that consists of three levels, i.e. at level 1 was the process of sending and returning process; level 2 which consisted of several performance attributes in SCOR; and level 3 which is comparing the KPI (Key Performance Indicator) at level 1 and 2 to see the level of the interest of the KPI (Key Performance Indicator). Researchers used 4 expert in this case, namely the head of the Supply Chain Department, Warehouse Department, Sales, and Manager/Head of Production.

Table 4. Pairwise comparison level 1

\begin{tabular}{lcc}
\hline Criteria & Deliver & Return \\
\hline Deliver & 1 & $1 / 7$ \\
Return & 7 & 1 \\
\hline
\end{tabular}

Based on the pairwise comparison in Table 4 above, prioritization using AHP was obtained as follows.
Table 5. Priority vector determination

\begin{tabular}{lccc}
\hline Criteria & Deliver & Return & $\begin{array}{c}\text { Priority } \\
\text { Vector }\end{array}$ \\
\hline Deliver & 0.125 & 0.125 & 0.125 \\
Return & 0.875 & 0.8749 & 0.875 \\
Total & 1 & 1 & 1 \\
\hline
\end{tabular}

a. Determine the value of $\lambda$ maks by calculating the average value (equation 2 )

$$
\lambda \operatorname{maks}=\frac{2+2}{2}=2
$$

b. Calculating the consistency index (CI),

Equation 3

$$
C I=\frac{2-2}{2-1}=0
$$

c. Calculating the consistency ratio (CR) equation 4 , with a value of $n=2$, then $R I=0.00$

$$
C R=\frac{0}{0,00}=0
$$

The same thing was done on the questionnaire and processed using Super Decisions software to determine the weight of each indicator's overall supply chain importance. The count was also carried out at level 2, namely calculating the weight, priority vector, and good consistency ratio. From the consistent weighing results, it can be seen in Table 6 and Table 7.

After weighing SCOR level 1 and level 2, the next step was to summarize all the weighted values generated to determine the overall priority. 
Table 6. Weighting results at level 1 and level 2

\begin{tabular}{lclcc}
\hline \multicolumn{1}{c}{ Level 1 } & Weight & \multicolumn{1}{c}{ Level 2 } & Local Weight & Global Weight \\
\hline Delivery & 0.125 & Reliability & 0.64912 & 0.08114 \\
& & Responsiveness & 0.27895 & 0.03487 \\
\multirow{2}{*}{ Return } & & Flexibility & 0.07193 & 0.00899 \\
& \multirow{2}{*}{0.875} & Reliability & 0.18839 & 0.16484 \\
& & Responsiveness & 0.08097 & 0.07085 \\
& & Asset Management & 0.73064 & 0.63931 \\
\hline
\end{tabular}

Table 7.Weighting results for key performance indicators

\begin{tabular}{clcc}
\hline KPI No. & \multicolumn{1}{c}{ KPI } & Local Weight & Global Weight \\
\hline D1.1 & Perfect order fulfillment & 0.16667 & 0.01352 \\
D1.2 & Order accuracy & 0.83333 & 0.06762 \\
D2.1 & Customer commit date & 0.875 & 0.03051 \\
D2.2 & \% Utility of truckload & 0.125 & 0.00436 \\
D3 & The speed of delivery for sudden request & 1 & 0.00899 \\
R1.1 & Good product return & 0.2019 & 0.03328 \\
R1.2 & Refurbish product return & 0.62233 & 0.10259 \\
R1.3 & Leased product return & 0.11545 & 0.01903 \\
R1.4 & EOL product return & 0.06032 & 0.00994 \\
R2.1 & \% Utility of truckload return & 0.73064 & 0.05176 \\
R2.2 & Deliver return cycle time & 0.18839 & 0.01335 \\
R2.3 & Return cycle time & 0.08096 & 0.00574 \\
R3.1 & Resell product & 0.63113 & 0.40349 \\
R3.2 & Repair product for send back & 0.17604 & 0.11254 \\
R3.3 & Release product & 0.10767 & 0.06883 \\
R3.4 & Disposal product & 0.08516 & 0.05444 \\
\hline & & & 1.00000 \\
\hline
\end{tabular}

\section{Calculation of OMAX and TLS}

The first step in a scoring system with an objective matrix is to determine the highest target value and lowest value achieved by each KPI (Key Performance Indicator), as follows (Paduloh et al. 2020; Yuniarti et al. 2013):

1. Target Calculation

2. Calculation of Realization (Performance)

3. Optimistic Value.

The increase in the target value that the company wants to achieve in the next 2 or 3 periods was determined subjectively by the company by considering the company's condition. The pessimistic value was the worst value that the company may achieve in a period determined subjectively by the company by considering its condition. The objective matrix (OMAX) model must determine the performance, realistic targets, optimistic values, and pessimistic values of the objective matrix (OMAX) (Fithri et al., 2017). To be more transparent, the following was a table for determining performance, realistic targets, optimistic values, and pessimistic values, which can be seen in Table 8 .

After determining performance, realistic targets, optimistic values, and pessimistic values, then determined the highest to lowest scale by scoring using OMAX (Objective Matrix). The aim was to determine each KPI target's achievement value in a certain period using a range of $0-10$ on each KPI.

- Calculation level 1 to level 2

$$
\begin{aligned}
& \text { Interpolation formulas } 0 \text { and } 3 \\
& \frac{\text { level 3-level } 0}{3-0}=\frac{75,000-60,000}{3}=5,000 \\
& \text { - Level } 2=75,000-5,000=70,000 \\
& \text { - Level } 1=70,000-5,000=65,000
\end{aligned}
$$

- Calculation level 4 to level 9

Interpolation formulas 3 and 10

$$
\frac{\text { level 10-level } 3}{10-3}=\frac{80,000-75,000}{7}=714
$$

Then each class was filled in with the following numbers with the formula:

Value level $\mathrm{X}=$ Value level $(\mathrm{X}+1)$ - Class Interval The calculation result is:
- $\quad$ Level $9=80.000-714=79,286$
- Level $8=79.286-714=78,571$
- $\quad$ Level $7=78.571-714=77,857$
- Level $6=77.857-714=77.143$
- Level $5=77.143-714=76.429$
- $\quad$ Level $4=76.429-714=75.71$ 
Table 8. Quantification data of stakeholder key performance indicators

\begin{tabular}{|c|c|c|c|c|c|c|}
\hline KPI No. & KPI & Unit & $\begin{array}{c}\text { Actual } \\
\text { Value }\end{array}$ & Target & $\begin{array}{l}\text { Optimistic } \\
\text { Value }\end{array}$ & $\begin{array}{l}\text { Pessimistic } \\
\text { Value }\end{array}$ \\
\hline D1.1 & Perfect order fulfillment & $\mathrm{Kg}$ & 79.000 & 75.000 & 80.000 & 60.000 \\
\hline D1.2 & Order accuracy & $\%$ & 87 & 80 & 100 & 60 \\
\hline D2.1 & Customer commit date & Jam & 18 & 20 & 18 & 24 \\
\hline D2.2 & $\%$ Utility of truckload & $\mathrm{Kg}$ & 600 & 500 & 600 & 350 \\
\hline D3 & $\begin{array}{l}\text { The speed of delivery for } \\
\text { sudden request }\end{array}$ & $\%$ & 80 & 70 & 90 & 60 \\
\hline R1.1 & Good product return & Unit & 100 & 93 & 75 & 100 \\
\hline R1.2 & Refurbish product return & Unit & 73 & 70 & 55 & 80 \\
\hline $\mathbf{R} 1.3$ & Leased product return & Unit & 50 & 40 & 35 & 60 \\
\hline R1.4 & EOL product return & Unit & 40 & 25 & 15 & 50 \\
\hline R2.1 & \% Utility of truckload return & $\mathrm{Kg}$ & 475 & 400 & 600 & 350 \\
\hline R2.2 & Deliver return cycle time & Jam & 22 & 20 & 18 & 24 \\
\hline $\mathbf{R} 2.3$ & Return cycle time & Jam & 20 & 22 & 20 & 24 \\
\hline R3.1 & Resell product & Unit & 60 & 60 & 75 & 100 \\
\hline R3.2 & Repair product for send back & Unit & 46 & 40 & 35 & 65 \\
\hline R3.3 & Release product & Unit & 30 & 15 & 0 & 30 \\
\hline R3.4 & Disposal product & Unit & 24 & 10 & 0 & 24 \\
\hline
\end{tabular}

Source: PT XYZ (2020)

Table 9. Results of scoring OMAX in deliver

\begin{tabular}{lcccccc}
\hline \multicolumn{1}{c}{ KPI } & D1.1 & D1.2 & D2.1 & D2.2 & D3 \\
\hline Performance & & 79,000 & 87 & 18 & 600 & 80 \\
Optimistic Value & 10 & 80,000 & 100.00 & 18.00 & 600.00 & 90.00 \\
& 9 & 79,286 & 97.14 & 18.29 & 585.71 & 87.14 \\
& 8 & 78,571 & 94.29 & 18.57 & 571.43 & 84.29 \\
& 7 & 77,857 & 91.43 & 18.86 & 557.14 & 81.43 \\
& 6 & 77,143 & 88.57 & 19.14 & 542.86 & 78.57 \\
& 5 & 76,429 & 85.71 & 19.43 & 528.57 & 75.71 \\
Target & 4 & 75,714 & 82.86 & 19.71 & 514.29 & 72.86 \\
& 3 & 75,000 & 80.00 & 20.00 & 500.00 & 70.00 \\
Pessimistic Value & 2 & 70,000 & 73.33 & 21.33 & 450.00 & 66.67 \\
\hline SCOR & 1 & 65,000 & 66.67 & 22.67 & 400.00 & 63.33 \\
\hline Weighing & 60,000 & 60.00 & 24.00 & 350.00 & 60.00 \\
\hline Value & 9 & 6 & 10 & 10 & 7 \\
\hline
\end{tabular}

Above is the calculation example for KPI D1.1. Furthermore, the calculation method was the same as the example above for all KPIs. The results of calculating the objective matrix (OMAX) and the traffic light system (TLS) on the entire KPI can be seen in the Table 9 and Tabel 10. Table 9 showed the OMAX and TLS scoring systems in the delivery or a delivery section.

The measured parameters had a KPI of 5 indicators, with the results of each score being 9,6 , 10,10 , and 7 . There were two indicators, namely D1.2 and D3, included in the yellow group, and the others are classified as green. The results of the multiplication value with the indicator weight were $0.12171,0.4057,0.3051,0.04359$, and 0.06294.

The calculation from table OMAX and TLS above on Return Reliability for KPI R1.1 obtained a score of 0 with a value of 0 and was included in the red category. For KPI R1.2 a score of 2 was obtained with a value of 0.205 and was included in the red category, for KPI R1. 3 obtained a score of 1 with a value of 0.019 and entered in the red category, for KPI R1.4 obtained a score of 1 with a value of 0.01 and entered in the red category. In the Return Responsiveness for KPI R2.1, a score of 6 was obtained with a value of 0.311 and was in the yellow category, for KPI R2.2 a score of 1 is obtained with a value of 0.013 and was included in the red category, for KPI R2.3 a score of 10 was obtained with a value of 0.06 and is included in the green color category. Whereas in Return Asset for KPI R3.1, a score of 3 was obtained with a value of 1.21 and included in the red category, for KPI R3.2 a score of 2 was obtained with a value of 0225 and entered in the red category, for KPI R3.3 the score was 0 with a value of 0 and included in the red color category, for KPI R3.4 a score of 0 was obtained with a value of 0 and was included in the red category. 
Table 10. Result of scoring OMAX in return

\begin{tabular}{lrrrrrrrrrrrr}
\hline \multicolumn{1}{c}{ KPI } & & R1.1 & $\mathbf{R 1 . 2}$ & $\mathbf{R 1 . 3}$ & $\mathbf{R 1 . 4}$ & $\mathbf{R 2 . 1}$ & $\mathbf{R 2 . 2}$ & $\mathbf{R 2 . 3}$ & $\mathbf{R 3 . 1}$ & $\mathbf{R 3 . 2}$ & $\mathbf{R 3 . 3}$ & $\mathbf{R 3 . 4}$ \\
\hline Performance & & 100 & 73 & 50 & 40 & 475 & 22 & 20 & 60 & 46 & 30 & 24 \\
Optimistic Value & 10 & 75.00 & 55.00 & 35.00 & 15.00 & 600.00 & 18.00 & 20.00 & 75.00 & 35.00 & 0.00 & 0.00 \\
& 9 & 77.57 & 57.14 & 35.71 & 16.43 & 571.43 & 18.29 & 20.29 & 72.86 & 35.71 & 2.14 & 1.43 \\
& 8 & 80.14 & 59.29 & 36.43 & 17.86 & 542.86 & 18.57 & 20.57 & 70.71 & 36.43 & 4.29 & 2.86 \\
& 7 & 82.71 & 61.43 & 37.14 & 19.29 & 514.29 & 18.86 & 20.86 & 68.57 & 37.14 & 6.43 & 4.29 \\
& 6 & 85.29 & 63.57 & 37.86 & 20.71 & 485.71 & 19.14 & 21.14 & 66.43 & 37.86 & 8.57 & 5.71 \\
& 5 & 87.86 & 65.71 & 38.57 & 22.14 & 457.14 & 19.43 & 21.43 & 64.29 & 38.57 & 10.71 & 7.14 \\
& 4 & 90.43 & 67.86 & 39.29 & 23.57 & 428.57 & 19.71 & 21.71 & 62.14 & 39.29 & 12.86 & 8.57 \\
Target & 3 & 93.00 & 70.00 & 40.00 & 25.00 & 400.00 & 20.00 & 22.00 & 60.00 & 40.00 & 15.00 & 10.00 \\
& 2 & 95.33 & 73.33 & 46.67 & 33.33 & 383.33 & 21.33 & 22.67 & 73.33 & 48.33 & 20.00 & 14.67 \\
& 1 & 97.67 & 76.67 & 53.33 & 41.67 & 366.67 & 22.67 & 23.33 & 86.67 & 56.67 & 25.00 & 19.33 \\
Pessimistic value & 0 & 100.00 & 80.00 & 60.00 & 50.00 & 350.00 & 24.00 & 24.00 & 100.00 & 65.00 & 30.00 & 24.00 \\
SCOR & & 0 & 2 & 1 & 1 & 6 & 1 & 10 & 3 & 2 & 0 & 0 \\
\hline Weighing & & 0.033 & 0.103 & 0.019 & 0.010 & 0.052 & 0.013 & 0.006 & 0.403 & 0.113 & 0.069 & 0.054 \\
\hline Value & & 0 & 0.205 & 0.019 & 0.01 & 0.311 & 0.013 & 0.06 & 1.21 & 0.225 & 0 & 0 \\
\hline
\end{tabular}

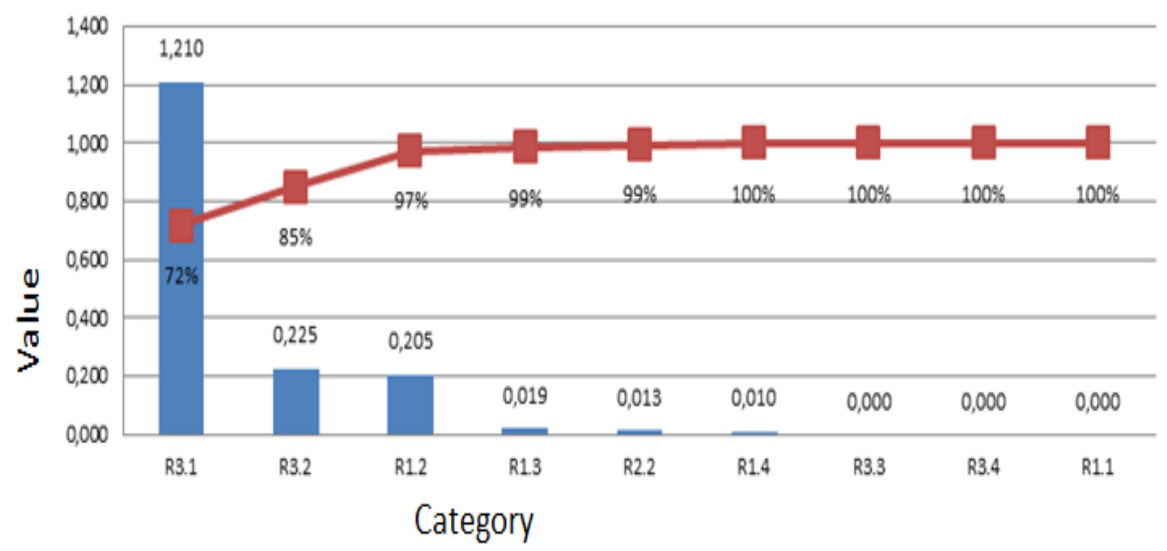

Figure 3. Graph of the highest value and lowest percentage of the returned products

\section{Improvement Analysis}

After scoring the OMAX system on each indicator and a traffic light system, the results showed that the delivery parameters have good performance, namely 3 KPIs out of 5 measured KPI indicators fall into the green category. Moreover, two others falled into the yellow category to increase delivery accuracy and speed in meeting urgent requests. Meanwhile, others must maintain their quality, such as the speed of delivery, quality, and quantity of delivery.

Improvements that can be made in the red category are carried out on the indicator that has the most considerable value, and the percentage of failure is smaller than before. It can be seen in Figure 3 in determining the indicators that can be improved first.

Figure 3 showed that R3.1 has the highest value and the lowest percentage, namely 1.210 and $72 \%$; it is also known that R3.1 is the number of products that can be resold against the returned product. Products returned to producers will be divided into three, products with good quality, products of good quality but decreasing slightly, and low-quality products.

\section{CONCLUSIONS AND RECOMMENDATIONS}

The performance measurement results along the reverse supply chain obtained 16 indicators, with nine red indicators, three yellow indicators, and four green indicators. The red indicator's priority improvements are Product Reselling, Feedback, Refurbish, Leased, Cycle Time, EOL, Product Release, Product Disposal, Good product category, and necessary actions. In this study, it was found that three categories of returned products were good quality products, good quality products but had decreased slightly, and low-quality products. in the reverse supply chain, Returned products of good quality were then resold. However, the products returned suffered a slight decline and were sold to companies that needed a lot of meat for products that did not take long to consume, such as meatballs. Moreover, products returned with low quality will be converted into animal food. The analysis results also showed the highest values and the lowest percentages, namely 1,210 and $72 \%$, namely the number of products that can be resold against the returned products. 


\section{REFERENCES}

Akkawuttiwanich P and Yenradee P. 2018. Fuzzy QFD approach for managing SCOR performance indicators. Computers and Industrial Engineering, 122 : 189-201. https://doi.org/10.1016/j.cie.2018.05.044.

Delipinar GE and Kocaoglu B. 2016. Using SCOR Model to Gain Competitive Advantage: A Literature Review. Procedia - Social and Behavioral Sciences. 229: 398-406. https://doi.org/10.1016/j.sbspro.2016.07.150.

Djatna T, Marimin, Massijaya MY, Asrol M, Baidowi T, Harison, Safriyana, Martini S. 2020. SCOR-based information modeling for managing supply chain performance of palm oil industry at Riau and Jambi Provinces, Indonesia. International Journal Supply Chain Management. 9(5): 75-89.

Fithri P and Firdaus I. 2017. Analisis Produktifitas Menggunakan Metode ObjectiveMatrix (OMAX) (Studi Kasus: PT. Moradon Berlian Sakti). Jurnal Optimasi Sistem Industri. 13(1): 548-555. https://doi.org/10.25077/josi.v13.n1.p548555.2014.

Hamidah NH, Deoranto P, dan Astuti R. 2013. Analisis Produktivitas Menggunakan Metode Objective Matrix (OMAX) : Studi Kasus pada Bagin Produksi Sari Roti PT Nippon Indosari Corpindo, TBK Pasuruan. Jurnal Teknologi Pertanian Analisis Produktivitas. 14(3): 215222.

Lu X, Zhang Y, Zhu L, Luo X, Hopkins DL. 2019. Effect of superchilled storage on shelf life and quality characteristics of $M$. longissimus lumborum from Chinese Yellow cattle. Meat
Science.

149 ,

$79-84$. https://doi.org/10.1016/j.meatsci.2018.11.014

Paduloh P, Djatna T, Muslich M, Sukardi S. 2020. Impact of reverse supply chain on bullwhip effects in beef supply. International Journal Supply Chain Management. 9(5): 1-11.

Paduloh P, Djatna T, Sukardi S, Muslich M. 2020. Uncertainty models in reverse supply chain: A review. International Journal Supply Chain Management. 9(2): 139-149.

Paduloh P dan Hardi PH. 2020. Analysis of Productivity Based on Kpi Case Study Automotive Paint Industry. Journal Engineering and Management in Industrial System, $\quad 8(1)$ : 1-12. https://doi.org/10.21776/ub.jemis.2020.008.01. 1.

Sirous R, Lopes R, dan Sirous S. 2016. Of Solar of Solar Energy Energy (JSER) of your Methodology each words. 1(1), 35-43.

Sundarakani B, Abdul RH, and Manikandan, S. 2018. Creating a competitive advantage in the global flight catering supply chain: a case study using SCOR model. International Journal Logistics Research and Applications. 21(5): 481-501. https://doi.org/10.1080/13675567.2018.14487 67.

Yuniarti R, Hamdala I, and Bagaskara RD. 2013. Performance Evaluation of Bran Suppliers With Anp and Omax Methods. Journal Engineering And Management In Industrial System. 5(1): 27-36. https://doi.org/10.21776/ub.jemis.2017.005.01. 4 